\title{
COMPARATIVE STUDY OF POLYMER FIBRE REINFORCED CONCRETE WITH CONVENTIONAL CONCRETE PAVEMENT
}

\author{
S.A Kanalli ${ }^{1}$, Ramu Palankar ${ }^{2}$, Bharath Kumar ${ }^{3}$, Praveen Kumar ${ }^{4}$, Prakash S.K \\ ${ }^{1}$ Assistant professor, ${ }^{2,3,4,5}$ Student, civil department, SDMCET Dharwad, Karnataka, India
}

\begin{abstract}
Road transportation is undoubtedly the lifeline of the nation and its development is a crucial concern. The traditional bituminous pavements and their needs for continuous maintenance and rehabilitation operations points towards the scope for cement concrete pavements. There are several advantages of cement concrete pavements over bituminous pavements. This paper emphasizes on POLYMER FIBRE REINFORCED CONCRETE PAVEMENTS, which is a recent advancement in the field of reinforced concrete pavement design. A comparative study of these pavements with the conventional concrete pavements has been made using Polypropylene fiber waste as fiber reinforcement.
\end{abstract}

Keywords: Polymer fibre concrete pavement, Polypropylene fiber waste as fiber reinforcement

\section{INTRODUCTION}

In a developing country such as India, road networks form the arteries of the nation. A pavement is the layered structure on which vehicles travel. It serves two purposes, namely, to provide a comfortable and durable surface for vehicles, and to reduce stresses on underlying soils. In India, the traditional system of bituminous pavements is widely used.

Locally available cement concrete is a better substitute to bitumen which is the by product in distillation of imported petroleum crude. It is a known fact that petroleum and its byproducts are dooming day by day. Whenever we think of a road construction in India it is taken for granted that it would be a bituminous pavement and there are very rare chances for thinking of an alternative like concrete pavements. Within two to three decades bituminous pavement would be a history and thus the need for an alternative is very essential. The perfect solution would be POLYMER FIBER REINFORCED CONCRETE PAVEMENTS, as it satisfies two of the much demanded requirements of pavement material in India, economy and reduced pollution. It also has several other advantages like longer life, low maintenance cost, fuel efficiency, good riding quality, increased load carrying capacity and impermeability to water over flexible pavements.

Fiber reinforced concrete pavements are more efficient than ordinary cement concrete pavement. "FRC is defined as composite material consisting of concrete reinforced with discrete randomly but uniformly dispersed short length fibers." The fibers may be of steel, polymer or natural materials [5]. FRC is considered to be a material of improved properties and not as reinforced cement concrete whereas reinforcement is provided for local strengthening of concrete in tension region. Fibers generally used in cement concrete pavements are steel fibers and organic polymer fibers such as polyester or polypropylene.

This is an environment friendly approach in the field of pavement construction as almost all sorts of polymer waste can be recycled and used as a reinforcing admixture in the concrete pavements. As waste polymers which are produced in large quantities are non-bio degradable they can cause immense environmental issues. Instead of disposing it we can efficiently make use of its properties in the pavement construction. Polymeric fibers normally used are either polyester or poly propylene. It should be $100 \%$ virgin synthetic fiber size $12 \mathrm{~mm}$ long and $0.45 \mathrm{~mm}$ diameter. It shall be mixed at the rate of $.25 \%$ of volume of concrete. Other fibers used are acrylic, aramid, carbon etc. These fibers reduce plastic shrinkage and substance cracking. This increase the toughness and post cracking integrity. Fibers named Fiber mesh and Recron $3 \mathrm{~S}$ are now produced by FIBERCOM-CF Company Ltd USA and in India Fibers like polypropylene and Recron 3S are manufactured by Reliance Industries Ltd.

\subsection{Polypropylene}

Polypropylene is one of the cheapest and abundantly available polymers. Polypropylene fibers are resistant to most chemical attacks. Its melting point is high (about 165 degrees centigrade). So that it can withstand a working temp, as (100 degree centigrade) for short periods without detriment to fiber properties. 


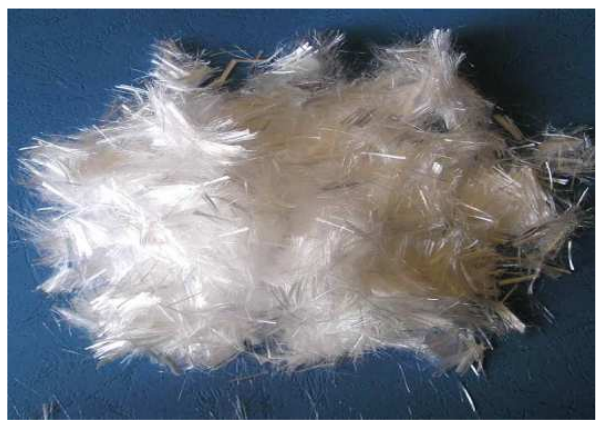

Fig 1 Polypropylene fiber

\subsubsection{History of Polypropylene}

Propylene was first polymerized to a crystalline isotactic polymer by Giulio Natta as well as by the German chemist Karl Rehn in March 1954.This pioneering discovery led to large-scale commercial production of isotactic polypropylene by the Italian firm Montecatini from 1957 onwards. Syndiotactic polypropylene was also first synthesized by Natta and his coworkers[9].

\section{METHODOLOGY}

A preliminary study on compressive strength, tensile strength and flexural using different proportions of polypropylene fibers resulted in an varying ratio of fiber dosage of 0.25 percent by volume of concrete. In the present study, experimental concrete cubes of size $150 \mathrm{~mm} \times 150 \mathrm{~mm}$, in thickness of $150 \mathrm{~mm}$ and cylinder of diameter $150 \mathrm{~mm}$ and height of $300 \mathrm{~mm}$, both with PCC (plain concrete) and OPFRC (optimum fibre reinforced concrete) with experimental fibers were cast and tested for compression, tensile for 7 and 28 days of curing[8]. The short term compressive strength test was carried out to study if there is any reduction in strength due to possible degradation of the fibers in the concrete's alkaline environment. A concrete beam of size $150 \mathrm{~mm} x$ $150 \mathrm{~mm} \times 700 \mathrm{~mm}$ were casted and tested for flexural strength after 7 and 28 days.

\subsection{Materials}

Ordinary Portland Cement (OPC) of grade 43 conforming to IS:12269 was used for the studies. Locally available quartzite aggregate with a maximum size of aggregate of $20 \mathrm{~mm}$ down size, and a pit sand (locally known as badrapur sand), were used as coarse aggregate and fine aggregate, respectively. The discrete polypropylene fibers of $12 \mathrm{~mm}$ length, used in the study were tested for salient properties and the test results are presented.

\subsection{Mix Proportion}

The FRC mix was prepared by adding 0.25 percent (by volume of concrete) fibers of $12 \mathrm{~mm}$ length to PCC mix. The fibers were added to the dry mix first and then water was added as this method appeared to produce a uniform FRC mix. The PCC and OPFRC mixes were used for laying the Pavement Quality Control (PQC) cubes, for preparation of test specimen for tensile strength test and for short term compressive strength.

Cement used shall be OPC 43 grade. Coarse sand of fineness modulus 2.42, washed and stone aggregate of $20 \mathrm{~mm}$ down size with minimum fineness modulus of 5.99 shall be used. PFRC has been provided with a design mix of 1:1.5:3 grading. The concrete shall have a flexural strength of $40 \mathrm{~kg} / \mathrm{m}^{2}$ at 28 days. Water cement ratio shall be as per IS specification mentioned for M30 grade concrete.

The code IRC: 44-2008 is followed for cement concrete mix designs for pavements with fibers.

\section{CONCRETE MIX DESIGN}

\subsection{Mix Design for M20}

Stipulation for Proportion

a) Grade designation $=$ M20

b) Type of cement $=$ Portland slag cement 43 grade conforming to IS8112

c) Max nominal size of the aggregate $=20 \mathrm{~mm}$

d) Min cement content $=320 \mathrm{~kg} / \mathrm{cu}-\mathrm{m}$

e) $\mathrm{Max} \mathrm{W} / \mathrm{C}$ ratio $=0.55$

f) Exposure condition $=$ Moderate

g) Type of aggregate $=$ Crushed angular

h) Max cement content $=425 \mathrm{~kg} / \mathrm{cu}-\mathrm{m}$

\subsection{Test Data}

a) Cement-Portland Slag cement 43 grade

b) Specific Gravity of cement $=3.15$

c) Specific Gravity of coarse aggregates $=2.8$

d) specific Gravity of fine aggregate $=2.67$

e) Sand confirming to zone-II

Target mean strength for mix proportion is given by $\mathrm{fck}=\mathrm{fck}+1.65 * \mathrm{~s}$

$$
=20+1.65 * 4 \text { (value is according to IS } 10262: 2009)
$$$$
=26.6 \mathrm{~N} / \mathrm{mm}^{2}
$$

From Table 5 of IS $10262: 2009$

$\mathrm{W} / \mathrm{C}$ ratio adopted is 0.55

\section{Mix Calculation}

a) Volume of concrete $=1 \mathrm{cu}-\mathrm{m}$

b) Volume of cement $=$ (mass of cement/sp.gr of cement $)^{*}(1 / 1000)$

$$
\begin{aligned}
& =(338.18 / 3.15) *(1 / 1000) \\
& =0.1074 \mathrm{cu}-\mathrm{m}
\end{aligned}
$$


c) Volume of water $=$ (mass of water $/$ sp.gr of water $)^{*}(1 / 1000)$

$$
\begin{aligned}
& =(186 / 1) *(1 / 1000) \\
& =0.816 \mathrm{cu}-\mathrm{m}
\end{aligned}
$$

d) Volume of aggregate $=1-(0.1074+0.186)$

$$
=0.7066 \mathrm{cu}-\mathrm{m}
$$

e) Mass of coarse aggregate $=\mathrm{e}^{*}$ vol of fine agg $*$ sp.gr of fine agg * 1000

$$
\begin{aligned}
& =0.7066 * 0.39 * 2.62 * 1000 \\
& =722.00 \mathrm{~kg}
\end{aligned}
$$

Cement $=338.18 \mathrm{~kg} \quad$ Water $=186 \mathrm{~kg} / \mathrm{cu}-\mathrm{m} \quad$ F.A $=722.00$ kg/cu-m

$$
\text { C.A }=1284.45 \mathrm{~kg} / \mathrm{cu}-\mathrm{m} \quad \mathrm{W} / \mathrm{C}=\mathbf{0 . 5 5}
$$

- $\quad$ Max W/C for $20 \mathrm{~mm}$ aggregate $=186$ litre

- Estimated water content for $50 \mathrm{~mm}$ slump = 186 litre

\section{Calculation of Cement Content:}

- $\mathrm{W} / \mathrm{C}=0.55$

- Cement content $=186 / 0.55=338.18 \mathrm{~kg} / \mathrm{cu}-$ $\mathrm{m}>320 \mathrm{~kg} / \mathrm{cu}-\mathrm{m} \&$ less than $425 \mathrm{~kg} / \mathrm{cu}-\mathrm{m}$

Hence this value can be adopted.

- Proportion of volume of coarse aggregate \& fine aggregate content $=\mathrm{W} / \mathrm{C}=0.5=0.62$

- In present case $\mathrm{W} / \mathrm{C}$ ratio is $=0.55$

- Therefore, Vol of coarse aggregateis required to be increased to decrease the fine aggregate content.

- As W/C is lowered by 0.05 , proportion of volume of coarse aggregate is decreased by 0.01 @ a rate of \pm 0.02 for every \pm 0.05 change in W/C

- Volume of coarse aggregate $=0.61$

- $\quad$ Volume of fine aggregate $=0.39$

- As W/C is lowered by 0.05 , proportion of volume of coarse aggregate is decreased by 0.01 @ a rate of \pm 0.02 for every \pm 0.05 change in W/C

- $\quad$ Volume of coarse aggregate $=0.61$

- Volume of fine aggregate $=0.39$.

The arrived mix proportion by weight is $1: 1.5: 3$

\section{RESULTS}

\subsection{Salient Properties of OPFRC from Laboratory}

\section{Study}

OPFRC exhibited increase in 28 day compressive and flexural strength by about 21 percent and 6.4 percent, respectively, as compared to control mix. It also exhibited a significant reduction in drying shrinkage. The drying shrinkage of control concrete was 0.062 percent while that of the FRC was 0.03 percent.

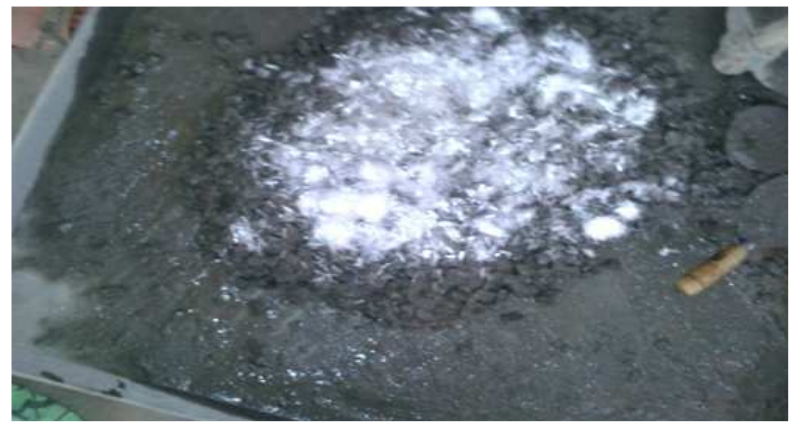

Fig 2 Mixing polypropylene fibers with concrete in lab

\begin{tabular}{|c|c|c|c|}
\hline Trial & $\begin{array}{l}\text { Load } \\
\text { (kn) }\end{array}$ & $\begin{array}{l}\text { Average } \\
\text { load (kn) }\end{array}$ & $\begin{array}{l}\text { Compressive } \\
\text { strength }\left(\mathbf{n} / \mathbf{m m}^{2}\right)\end{array}$ \\
\hline 1. & 720 & \multirow[b]{3}{*}{740} & \multirow[b]{3}{*}{32.88} \\
\hline 2. & 760 & & \\
\hline 3. & 740 & & \\
\hline
\end{tabular}

\subsection{COMPRESSIVE STRENGTH TEST:}

Table 1: 7- Day cube test result for plain concrete (Check for M20 mix design)

\begin{tabular}{|c|c|c|}
\hline Trial & $\begin{array}{l}\text { Load } \\
\text { (kn) }\end{array}$ & $\begin{array}{l}\text { Compressive } \\
\text { strength }\left(\mathbf{n} / \mathbf{m m}^{\mathbf{2}}\right)\end{array}$ \\
\hline 1. & 450 & 20.3 \\
\hline 2. & 470 & 21.29 \\
\hline 3. & 440 & 19.93 \\
\hline
\end{tabular}

Table 2: $28^{\mathrm{TH}}$ day cube testing result for plain concrete

Calculation:

Compressive strength $=$ Load $/$ area

$$
\begin{aligned}
& =740 / 225 \\
& =32.88 \mathrm{~N} / \mathrm{mm}^{2}
\end{aligned}
$$

Average $28^{\text {th }}$ day strength from above data is $32.88 \mathrm{~N} / \mathrm{mm}^{2}$

Table 3: Split tensile strength test for (pcc)28 days:

\begin{tabular}{|c|c|c|c|}
\hline $\begin{array}{c}\text { Trial } \\
\text { no }\end{array}$ & $\begin{array}{c}\text { load } \\
\text { (kn) }\end{array}$ & $\begin{array}{c}\text { Average } \\
\text { load }\end{array}$ & $\begin{array}{c}\text { Tensile } \\
\text { strength }\left(\mathbf{n} / \mathbf{m m}^{\mathbf{2}} \mathbf{)}\right.\end{array}$ \\
\hline 1. & 200 & \multirow{2}{*}{206.67} & \multirow{2}{*}{29.80} \\
\cline { 1 - 2 } 2. & 210 & & \\
\cline { 1 - 2 } 3. & 210 & & \\
\hline
\end{tabular}

Calculation:

Tensile strength $=2 \mathrm{P} /(3.142 \mathrm{DL})$

$2(206.67) /(3.142 \times 15 \times 30)$

$29.80 \mathrm{~N} / \mathrm{mm}^{2}$ 
Table 4: Flexural strength test

\begin{tabular}{|l|l|l|l|}
\hline Beam no & $\begin{array}{l}\text { Load } \\
\text { (kn) }\end{array}$ & $\begin{array}{l}\text { Average } \\
\text { load (kn) }\end{array}$ & $\begin{array}{l}\text { Flexural } \\
\text { strength(n/mm } \mathbf{n} \text { ) }\end{array}$ \\
\hline 1. & 2100 & \multirow{2}{*}{2096.67} & \\
\cline { 1 - 2 } 2. & 2090 & & 18.87 \\
\cline { 1 - 2 } 3. & 2100 & & \\
\hline
\end{tabular}

Calculation:

Flexural strength $=\mathrm{PI} / \mathrm{bd}^{2}$

$$
\begin{aligned}
& =2096.67 \times 9\left(10 \times 10^{2}\right) \\
& =18.87 \mathrm{~N} / \mathrm{mm}^{2}
\end{aligned}
$$

Table 5: Compressive strength for PFRC

\begin{tabular}{|l|l|l|l|l|l|}
\hline \multirow{2}{*}{$\begin{array}{l}\text { S.l. } \\
\text { no. }\end{array}$} & $\begin{array}{l}\text { \% } \\
\text { Polymer } \\
\end{array}$ & \multirow{2}{*}{ Fiber } & \multicolumn{2}{c|}{$\begin{array}{c}\text { Average } \\
\text { load (kn) }\end{array}$} & \multicolumn{2}{c|}{$\begin{array}{c}\text { Compressive } \\
\left.\text { strength(nd } \mathbf{m m}^{\mathbf{2}}\right)\end{array}$} \\
\cline { 3 - 6 } & & $\begin{array}{l}\mathbf{7} \\
\text { Days }\end{array}$ & $\begin{array}{l}\mathbf{2 8} \\
\text { Days }\end{array}$ & $\mathbf{7}$ Days & $\mathbf{2 8}$ Days \\
\hline 1. & .25 & 470 & 750 & 20.88 & 33.33 \\
\hline 2. & 0.5 & 480 & 800 & 21.33 & 35.55 \\
\hline 3. & .75 & 510 & 880 & 22.66 & 39.11 \\
\hline 4. & 1 & 430 & 820 & 19.11 & 36.44 \\
\hline 5. & 1.25 & 420 & 760 & 18.66 & 33.77 \\
\hline
\end{tabular}

Table 6: Tensile strength of PFRC

\begin{tabular}{|l|l|l|l|}
\hline $\begin{array}{l}\text { S.l. } \\
\text { no. }\end{array}$ & $\begin{array}{c}\text { \%Polymer } \\
\text { fiber }\end{array}$ & $\begin{array}{l}\text { Average } \\
\text { load (kn) }\end{array}$ & $\begin{array}{l}\text { Tensile } \\
\text { strength }\left(\mathbf{n} / \mathbf{m m}^{\mathbf{2}}\right)\end{array}$ \\
\cline { 3 - 4 } & & 28 days & \\
\hline 1. & .25 & 220 & 31.11 \\
\hline 2. & 0.5 & 240 & 33.94 \\
\hline 3. & .75 & 270 & 38.9 \\
\hline 4. & 1 & 260 & 36.77 \\
\hline 5. & 1.25 & 240 & 33.94 \\
\hline
\end{tabular}

Table 7: Flexural Strength of PFRC

\begin{tabular}{|l|l|l|l|}
\hline S.l. no. & $\begin{array}{c}\text { \%polymer } \\
\text { Fiber }\end{array}$ & $\begin{array}{c}\text { Average } \\
\text { load (kn) }\end{array}$ & $\begin{array}{c}\text { Flexural } \\
\left(\mathbf{n} / \mathbf{m m}^{\mathbf{2}}\right)\end{array}$ \\
\cline { 3 - 4 } & & $\mathbf{2 8 d a y s}$ & \multicolumn{2}{|c|}{$\mathbf{2 8 d a y s}$} \\
\hline 1. & .25 & 2100 & 18.9 \\
\hline 2. & 0.5 & 2180 & 19.62 \\
\hline 3. & .75 & 2250 & 20.25 \\
\hline 4. & 1 & 2200 & 19.62 \\
\hline 5. & 1.25 & 2130 & 19.17 \\
\hline
\end{tabular}

\subsection{Tensile Strength of Concrete}

The cylinder of diameter $\mathrm{mm}$ and of height $300 \mathrm{~mm}$ is casted and tested for the tensile strength with the varying ratio of fiber dosage ranging from $0.25 \%$ of volume of concrete and the specimen is tested for split tensile test after 7 days and 28 days then the result will be compared with the plain concrete cylinder, and the graph is plotted.

\section{Tensile strength of PFRC for:}

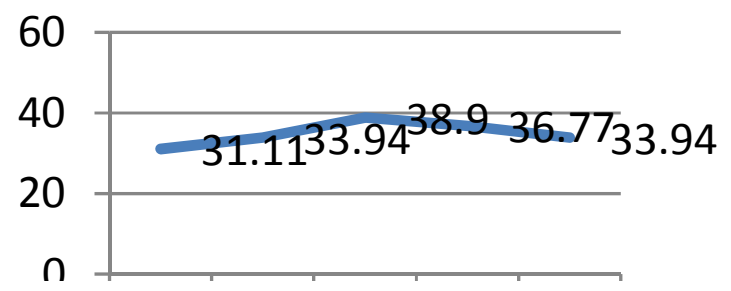

Fig 3: Graph showing Tensile Strength of PFRC for 28 days.

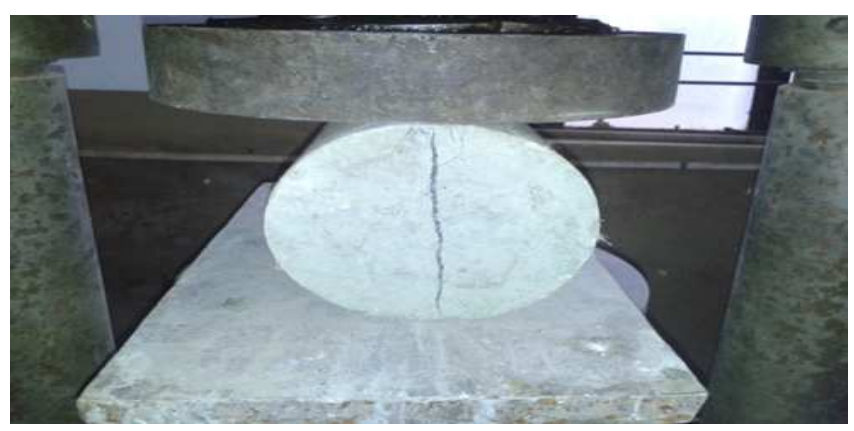

Fig 4 Tensile strength test for PFRC Cylinder

\subsection{Compressive Strength of Concrete}

The cubes of dimension $150 \mathrm{~mm} \times 150 \mathrm{~mm} \times 150 \mathrm{mmwith}$ the varying ratio of fiber dosage ranging from $0.25 \%$ of volume of concrete were casted and tested for compressive strength after 7 and 28 days of curing.

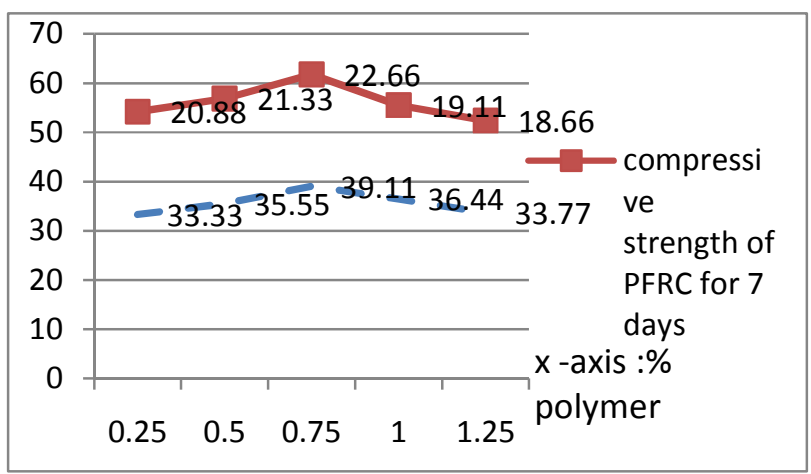




\subsection{Flexural Strength of the Concrete Beam}

The beam of size $700 \mathrm{~mm} \times 150 \mathrm{~mm} \times 150 \mathrm{~mm}$ is casted and tested under 3 point loading for 7 and 28 days with the varying ratio of fiber dosage of $0.25 \%$ of volume of concrete.

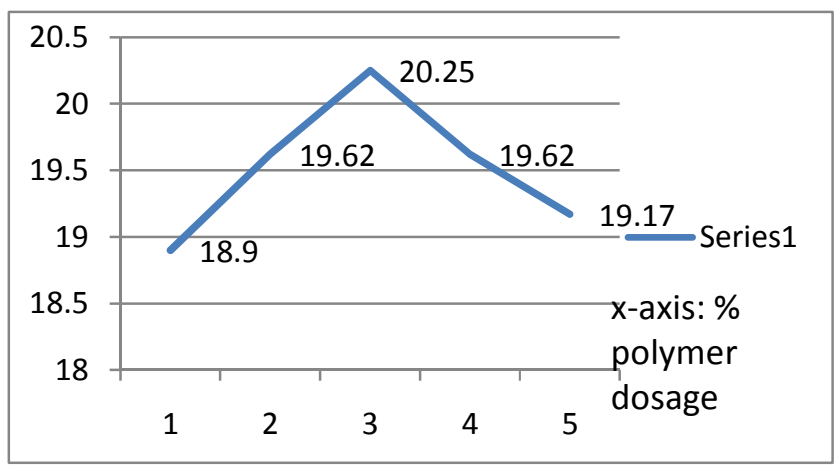

Fig 5: Graph showing Flexural Strength of PFRC for 28 days.

\section{INFERENCES OF THE STUDY}

The following inferences are made from this study on FRC made with polypropylene fibers of $12 \mathrm{~mm}$ length:

1. FRC in thicknesses of $100 \mathrm{~mm}$ or more can be used for pavements or other similar application.

2. There will be shrinkage reduction in concrete surface.

3. The water to cement ratio will be decreased because of low permeability.

4. The results of this study promote effective disposal of these non bio -degradable synthetic fibers.

\section{CONCLUSIONS}

PFRC can be used advantageously over normal concrete pavement. Polymeric fibers such as polyester or polypropylene are being used due to their cost effective as well as corrosion resistance. PFRC requires specific design considerations and construction procedures to obtain optimum performance. The higher initial cost by $15-20 \%$ is counterbalanced by the reduction in maintenance and rehabilitation operations, making PFRC cheaper than flexible pavement by $30-35 \%$. In a fast developing and vast country like India, road networks ensure mobility of resources, communication and in turn contribute to growth and development.

Resistance to change though however small disturbs our society hence we are always reluctant to accept even the best. Its high time that we overcome the resistance and reach for the peaks. PFRC opens a new hope to developing and globalizing the quality and reshaping the face of the "True Indian Roads".

\section{REFERENCES}

[1]. Dr.K.M Soni, "Fiber Reinforced Concrete in Pavements", NBM\&CW vol 12, pp 178-181, May 2007.

[2]. Dr.S.S.Seehra, An Innovative concrete technological development of fully mechanized construction of cement concrete pavement", NBM\&BW vol 12 pp76-93, ,March 2007.

[3]. B.K.AGRAWAL, Introduction to Engineering Materials", 4th edition, Tata Mc Grawhill Publishing company ltd, pp194195

[4]. KENNETH G. BUDHINSKI, MICHEL K. BUDHINSKI," Engineering materials-Properties \& selection", 8th edition, Prentice Hall India, pp 194-195

[5]. Gopal Krishna, Key role of chemical admixtures for pavement quality concrete", NBM\&BW vol 13, pp166-169, July 2007

[6]. J.M.L. Reis" Fracture and flexure characterization of natural fibers-reinforced polymer concrete" Construction and Building Materials vol 20 pp 673-678, Nov 2006

[7]. Amnon Katz, "Environmental impact of steel and FRP reinforced polymer", Journal for composite for construction vol 8 no.6 pp 48-488. , Nov/Dec 2004.

[8]. M S Shetty "concrete Technology" S Chand Publication 1982 12th Editio,2007.

[9].

http://cedb.asce.org/cgi/wwwdisplay.cg(12sep2007).

[10]. The code IRC: 44-2008 "for cement concrete mix designs for pavements with fibers"

\section{BIOGRAPHIES}

Prof Shravan A.Kanalli (Shravan A.Kanalli is an MTech graduate in Transportation Engineering and Management from BMS College of Engineering and Technology, Bengaluru. He is currently working as Assistant Professor in SDM College of Engineering and Technology, Dharwad, Karnataka, India since April 2012)

Ramu Palankar is a BE graduate from SDM College of engineering and Technology, Dharwad is currently working for HFLC (Reliance 4G)

Bharath Kumar is an BE graduate from SDM College of engineering and Technology, Dharwad is currently working for Shree Sai enterprises Pvt Ltd.

Praveen Kumar is an BE graduate from SDM College of engineering and Technology, Dharwad is currently working for Sattava Engineering and Construction Pvt Ltd.

Prakash S.K is an BE graduate from SDM College of engineering and Technology, Dharwad is currently working for Nikita built Tech. 